University of Pennsylvania Carey Law School

Penn Law: Legal Scholarship Repository

Faculty Scholarship at Penn Law

$11-1999$

\title{
Judgment Proofing, Bankruptcy Policy, and the Dark Side of Tort Liability
}

Charles W. Mooney Jr.

University of Pennsylvania Carey Law School

Follow this and additional works at: https://scholarship.law.upenn.edu/faculty_scholarship

Part of the Bankruptcy Law Commons, Civil Procedure Commons, Dispute Resolution and Arbitration Commons, Economic Policy Commons, Economics Commons, Law and Economics Commons, Torts

Commons, and the Work, Economy and Organizations Commons

\section{Repository Citation}

Mooney, Charles W. Jr., "Judgment Proofing, Bankruptcy Policy, and the Dark Side of Tort Liability" (1999). Faculty Scholarship at Penn Law. 1289.

https://scholarship.law.upenn.edu/faculty_scholarship/1289

This Article is brought to you for free and open access by Penn Law: Legal Scholarship Repository. It has been accepted for inclusion in Faculty Scholarship at Penn Law by an authorized administrator of Penn Law: Legal Scholarship Repository. For more information, please contact PennlawIR@law.upenn.edu. 


\title{
Judgment Proofing, Bankruptcy Policy, and the Dark Side of Tort Liability
}

\author{
Charles W. Mooney, Jr.*
}

One need not be an astute student of the law of obligations to appreciate Professor Schwarcz's comprehensive rebuttal of Professor LoPucki's recent articles on judgment proofing. ${ }^{1}$ Schwarcz argues compellingly that judgment proofing is not likely to occur in arm's length contexts. Although judgment proofing may be more likely in non-arm's length situations, he also demonstrates persuasively that current doctrine is up to the task without the need for additional regulation.

Schwarcz correctly observes that the principal potential victims of judgment proofing are involuntary (i.e., tort) creditors of business debtors. ${ }^{2}$ However, neither Schwarcz nor LoPucki gives much attention to the significance of the underlying policies or characteristics of tort liability to the matter of judgment proofing. ${ }^{3}$ My observations address tort claims in this context. I shall not devote my brief allotted space to a broad critique of the Schwarcz-LoPucki dialogue. Instead, this essay outlines a different path for future scholarship and policy debates. In particular, that path must pay attention to both the nature and effects of tort liability.

Schwarcz and LoPucki both proceed on the implicit assumption that tort claimants, even claimants against insolvent (judgment proof) debtors, should be paid. Addressing debtors that cannot pay, however, inevitably implicates bankruptcy policy. In my view, the purpose of the bankruptcy system should be the enforcement of legal rights against a debtor in financial distress. Bankruptcy is a branch of civil procedure-a judicial process in which legal rights and entitlements are determined and remedies are provided. ${ }^{4}$ Accord-

* Interim Dean and Professor of Law, University of Pennsylvania Law School.

1. See Lynn M. LoPucki, The Death of Liability, 106 YALE L.J. 1 (1996); Lynn M. LoPucki, The Essential Structure of Judgment Proofing, 51 STAN. L. REV. 147 (1998); Steven L. Schwarcz, The Inherent Irrationality of Judgment Proofing, 52 STAN. L. REV. 1 (1999); see also Lynn M. LoPucki, Virtual Judgment Proofing: A Rejoinder, 107 YALE L.J. 1413 (1998); James J. White, Corporate Judgment Proofing: A Response to Lynn LoPucki's The Death of Liability, 107 YALE L.J. 1363 (1998).

2. See Schwarcz, supra note 1 , at 4-5 \& nn.13-14.

3. This is not necessarily a criticism; neither set out to examine tort law.

4. "Bankruptcy is civil procedure-no less but absolutely no more." Charles W. Mooney, Jr., Hosing Down Senior Claims with a Quicker and Dirtier Chapter 11, 72 WASH. U. L.Q. 1153, 1158 
ingly, the creation and attributes of the legal rights that bankruptcy should enforce are determined primarily by nonbankruptcy state and federal law. These rights include property rights, claims in contract and tort, governmental interests such as claims for taxes and fines, zoning restrictions, licensing requirements, and most other legal relationships with a debtor, such as the interests of the debtor's shareholders, partners, and employees. As a first principle, then, Schwarcz's and LoPucki's intuitions are correct insofar as tort claimants have legally enforceable claims.

When a debtor is insolvent it is sometimes appropriate to apply different rules in the interest of maximizing the recoveries of those with legal entitlements or to achieve other normatively desirable goals. One set of insolvency-based rule changes is the body of doctrine generally known as "fraudulent transfer." Under both Bankruptcy Code section 548 and the Uniform Fraudulent Transfer Act (and the earlier Uniform Fraudulent Conveyance Act), obligations incurred for less than "reasonably equivalent value" ("fair consideration," under the earlier act) are avoidable if they are incurred while the debtor is insolvent. 5 Avoidance based on the inadequacy of value, as opposed to actual fraudulent intent, is often called "constructive" fraud. Although there may be no consensus on the precise normative basis for avoiding transfers of property or the incurrence of obligations by an insolvent debtor for less than reasonably equivalent value, there does seem to be a general consensus that fraudulent transfer law, including the constructive fraud rules, should be retained. 6

Note that the constructive fraud doctrine appears to catch some purely innocent behavior that has the effect of damaging an insolvent debtor's creditors (by taking away assets or by giving rise to a competing obligation).?

(1994) (commenting on Lynn M. LoPucki and William C. Whitford, Compensating Unsecured Creditors for Extraordinary Bankruptcy Reorganization Risks, 72 WASH. U. L.Q. 1133 (1994)).

5. 11 U.S.C. $§ 548(\mathrm{a})(1)(B)(i)(1993$ \& Supp. 1999); UNIF. FRAUDULENT TRANSFER ACT $\S$ 5(a) (1984); UNIF. FRAUDULENT CONVEYANCE ACT $\$ 4$ (1918). There are triggers other than insolvency that also will invoke fraudulent transfer doctrine. See, e.g., 11 U.S.C. $\$ 548(a)(1)(B)(i i)(I I)$ (1993 \& Supp. 1999) (debtor "engaged . . . or . . . about to engage in business or a transaction, for which any property remaining with the debtor was an unreascnably small capital"); 11 U.S.C. $\S$ 548(a)(1)(B)(ii)(III) (1993 \& Supp. 1999) (debtor "intended to incur ... debts that would be beyond the debtor's ability to pay as such debts matured"). References in this essay to "insolvent" or "insolvency" are intended to embrace these other triggers as well.

6. For example, David Carlson questioned the economic efficiency of fraudulent transfer law, but concluded nonetheless that the doctrine is supportable on non-efficiency-based normative grounds - it is wrong to take assets away from creditors and give them to others. See David Gray Carlson, Is Fraudulent Conveyance Law Efficient?, 9 CARDOZO L. REV. 643 (1987). Some, however, have questioned the wisdom of applying fraudulent transfer law in specific contexts. See, e.g., Douglas G. Baird \& Thomas H. Jackson, Fraudulent Conveyance Law and Its Proper Domain, 38 VAND. L. REV. 829 (1985).

7. "The most important aspect of the original 1915 statute [the Uniform Fraudulent Conveyance Act] was that it codified in fraudulent conveyance law a concept usually called 'constructive fraud' or 'presumptive fraud.' Both terms are misnomers because the new concept permitted a creditor to avoid-to set aside-a transfer even though the debtor was entirely innocent of any 
Stated otherwise, under constructive fraud doctrine a creditor normally should not be allowed to claim an amount that is substantially greater than the value that the creditor has contributed to the debtor.

Many - possibly most - tort claims incurred by an insolvent tortfeasor appear to meet the test for avoidability under fraudulent transfer law. When the debtor's tort liability appears it is unaccompanied by any corresponding asset. 8 Had counsel for the debtors and non-tort creditors pursued this path, the results in huge bankruptcies involving mass tort claims in recent years might have been radically different. Forewamed of this theory, counsel for debtors and non-tort creditors who fail to pursue it in the future may act at their peril. 9 On the other hand, arguments typically are not made that tort claims, as opposed to contractual claims, may be avoidable on a fraudulent transfer theory. This is surprising, especially because Bankruptcy Code section 548 is so compellingly clear. ${ }^{10}$

There is a second aspect of tort liability that may bear on how seriously we take the potential for judgment proofing. Simply put, there is no consensus on why tort liability exists or what tort law is about. The principal rationales are deterrence, justice, and compensation. ${ }^{11}$ If critics are correct that

fraudulent intent. The statute defined circumstances in which the transfer was regarded as unfairly disadvantageous to the debtor's creditors, regardless of intent. ..." ELIZABETH WARREN \& JAY LAWRENCE WeSTBROOK, THE LAW OF DeBTORS AND CREDITORS 162 (3d ed. 1996) (emphasis added).

8. The analysis will not always be so simple, however. For example, one injured by a defective product may have paid the price for the product, thereby giving some value to the debtor. Also, difficult questions may arise as to when a tort obligation is incurred.

9. Steven Harris and I wamed of this possibility in a footnote in a 1994 article. See Steven L. Harris \& Charles W. Mooney, Jr., A Property-Based Theory of Security Interests: Taking Debtors ' Choices Seriously, 80 VA. L. REV. 2021, 2066 n.134 (1994).

10. The Uniform Fraudulent Transfer Act may be less clear, as its drafters apparently may not have thought about tort claims as obligations affected by the statute. See UNIF. Fraudulent TRANSFER ACT $§ 6(5)$ (1984) (providing the time when an obligation is incurred if the obligation is "oral" or "evidenced by a writing," perhaps suggesting that the drafters were not thinking of tort claims as obligations).

Note that the idea of subordinating tort claims in bankruptcy flies against arguments that contract claims-even secured contract claims-should be subordinated to tort claims in bankruptcy. See David W. Leebron, Limited Liability, Tort Victims, and Creditors, 91 COLUM. L. REV. 1565, 1646-1650 (1991); Lynn M. LoPucki, The Unsecured Creditor's Bargain, 80 VA. L. REV. 1887, 1908-14 (1994). Avoiding tort claims under fraudulent transfer law would exacerbate the negative extemalities considered by Leebron and LoPucki, to be sure. But honoring many types of tort claims likewise does substantial violence to the egalitarian (and other) goals of fraudulent transfer law. This violence should not be ignored. Perhaps it is time for torts scholars and bankruptcy scholars to join forces in exploring how to rationalize competing interests and norms.

11. See, e.g., Izhak Englard, The Philosophy of TORT Law (1993); Stephen R. Perry, Risk, Harm, and Responsibility, in PHILOSOPHICAL FOUNDations OF TORT LaW (David Owen, ed. 1995). For a brief critique of the deterrence theory, see Steven L. Harris \& Charles W. Mooney, Jr., Measuring the Social Costs and Benefits and Identifying the Victims of Subordinating Security Interests in Bankruptcy, 82 CORNELL L. REV. 1349, 1366-68 (1997). 
deterrence is a weak justification for tort liability, 12 deterrence must be an even weaker rationale in the case of an insolvent debtor. The debtor has no equity to lose! Moreover, inasmuch as fraudulent transfer doctrine will be invoked only in cases of insolvent debtors, application of that doctrine to tort liabilities may not present an unreasonable disruption of justice- and compensation-based conceptions of tort law. This is not the place to analyze fully tort theory or the normative comparisons between contract liabilities and tort liabilities. But if judgment proofing against tort liability is a concern, the nature of that liability cannot be ignored.

Finally, the wealth effects of tort law must be considered. Schwarcz argues against radical restrictions or regulatory responses to judgment proofing concerns which could "indiscriminately restrict the value creation - 'wealth, jobs, incomes, and new products for large numbers of people' - that comes with business and financial innovation." 13 The contours of tort law itself also may be restricting the creation of wealth. As we know it in the United States, tort law is wasteful and in general poorly compensates some victims while drastically overcompensating others (and rewarding their lawyers). Few would doubt that as a society we should provide for those who have been injured. But that position does not require a defense of current doctrine. ${ }^{14}$

The relationship between tort law and fraudulent transfer law is an important, albeit largely unnoticed, aspect of how tort claims-including mass torts-are dealt with in bankruptcy. This dark side of tort liability is its negative impact on the other creditors of an insolvent tortfeasor. It seems clear enough that a new debate should emerge about the effects of tort claims when viewed through the goals underlying tort law, fraudulent transfer law, and bankuptcy policy.

12. See, e.g., Stephen D. Sugarman, Doing Away with Personal InJury Law 3-24 (1989).

13. Schwarcz, supra note 1, at 53 (citing Paul Craig Roberts, Who Did More for Mankind, Mother Teresa or Mike Milken?, BUS. WK., Mar. 2, 1998, at 28).

14. Professor Sugarman launched one of the most trenchant critiques of current doctrine and its commonly-asserted justifications. In its place he proposed an altemative compensation and accident-reduction scheme. See SUGARMAN, supra note 12. 